\title{
Investigating the Effectiveness of Cognitive Vocabulary Strategy Instruction in Raising Learners' Metacognitive Awareness for Long-Term Mass Lexis Learning
}

\begin{abstract}
:
This paper reports on a study that investigates the role of learning vocabulary and the importance of intentionally instructing learners the techniques of vocabulary learning strategies. This study aimed at implementing a framework of Vocabulary Learning Strategies to enhance learners' Metacognitive awareness resulting in maximizing their lexis repertoire. It investigates a causal relationship between the direct instruction of VLS and its impact on improving learners Metacognitive strategies towards; learning and retaining vocabulary. It is between the first variable; teaching learners how to learn vocabulary (through the means of Vocabulary Learning Strategies); in other words, the effect of Metacognitive strategy training and the impact of this instruction -the second variable- on raising their Metacognitive awareness to become autonomous and maximize their vocabulary repertoire; leading to the development of lexical knowledge and retention. Our field work consists of a questionnaire designed in accordance and in reliance with Schmidtt's inventory of Vocabulary Learning Strategies. After gathering preliminary data from questionnaire analysis; a test is designed to serve the aim of spotting the VLS frequency use, and sum of strategies displayed. The test guides the construction of a step by step procedure to teach more elaborate strategies and enable learners become autonomous.
\end{abstract}

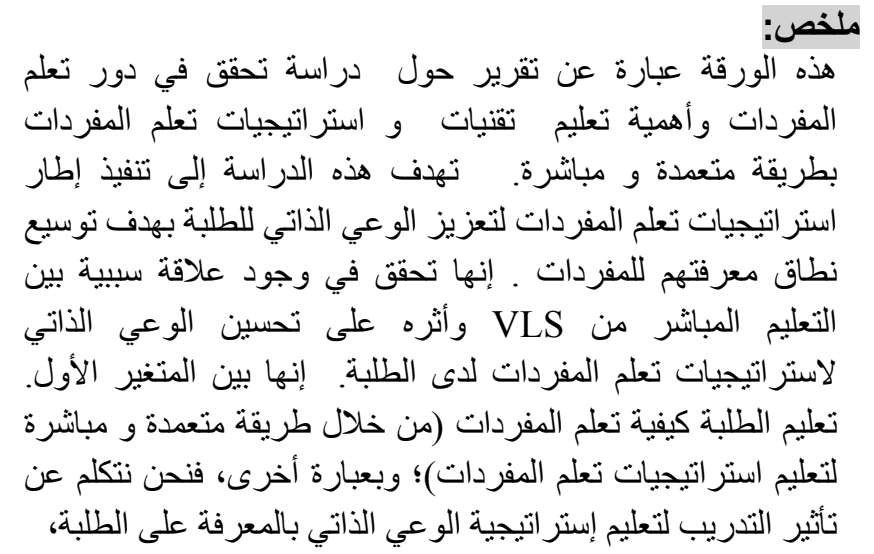

\section{Introduction:}

There are many factors that cause the students difficulties in learning. One of them is the method given by the teacher. Teaching English as a Foreign Language requires the use of effective learning method. 


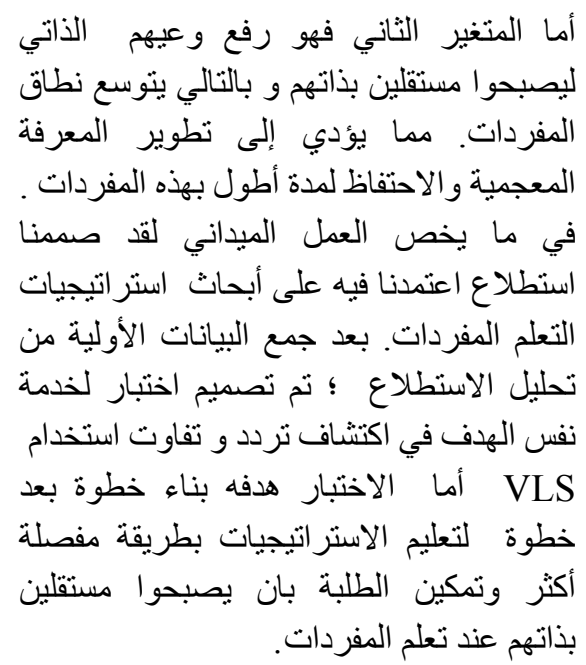

According to Richards and

Rodgers (1985: 16),

"Method is an umbrella

term for the specification and interrelation of theory and practice." Furthermore, they state that virtually all language teaching methods make the oversimplified assumption that what teachers do in the classroom can be conventionalized into a set of procedures that fits all contexts.

It means that a set of procedures or the techniques in teaching have an influence on the student's learning result. An increasingly deregulated procedures with a need for a flexible stretch of learning practice has led to greater emphasis on 'facilitating access to life long learning' (Council of the European Union, 2001: 11). Similarly, Brown (2001: 15) draws a distinction between methods as 'specific, identifiable clusters of theoretically compatible classroom techniques' and methodology as 'pedagogical practices in general...whatever considerations are involved in "how to teach" are methodological' (ibid.)

Vocabulary is defined as "a list of words in a language with their meaning" (Hornby, 2000: 1331). And in the process of vocabulary learning in particular, learning the aspects of the word surpasses the need to know a certain word in isolation. It means learners will come to know a word and all of its pivots to be discovered and tied together to form a mental lexicon map for vocabulary acquisition. Aitchison (2003:5) states that '[words] are organized into an intricate, interlocking system whose underlying principles can be discovered.' As for knowing a 'word', Taylor (1990: 1-3) had listed the seven degrees of knowing a word and all of these elements or degrees in combination make out of vocabulary learning an intricate process:

knowledge of the frequency of the word in language; knowledge of the register of the word; knowledge of collocation; knowledge of morphology; knowledge of semantics; knowledge of polysemy and knowledge of the equivalent of the word in the mother tongue. 
The dilemma with learning vocabulary, however, is that learners feel a certain lack of stock of the words. In the sense that they quickly run out of lexis when it comes to self-expression. Learners who have little knowledge of vocabulary will face some difficulties to understand the written as well as the oral language. Thornbury (2002: 13) says,

$$
\begin{aligned}
& \text { If you spend most of your time studying } \\
& \text { grammar, your English will not improve } \\
& \text { very much. You will see most } \\
& \text { improvement if you learn more words } \\
& \text { and expressions. You can say very little } \\
& \text { with grammar, but you can say almost } \\
& \text { anything with word. }
\end{aligned}
$$

Learners may get some difficulties in learning a language if they have a limited number of vocabularies. Thornbury (2002: 23) adds "The learner needs not only to learn a lot of words, but to remember them." It means that the success in mastering a language is determined by the size of the vocabulary one has learned and internalized. To master all the language skills, vocabulary knowledge is important; that has to be known by the learners and teachers must recognize the necessity for having a stretch of technique that make the learners interested in learning vocabulary. There are many techniques for making learners interested in what they are learning, especially in learning vocabulary. Brown (1994: 48) says, "Techniques are the specific activities manifested in the classroom that are consistent with a method and therefore in harmony with an approach as well." Rivers (in Thornbury, 2002: 144) states that;

$$
\begin{aligned}
& \text { Vocabulary cannot be taught, it can be } \\
& \text { presented, explained, included in all kind of } \\
& \text { activities and experienced in all manner of } \\
& \text { associations... but ultimately it is learned by } \\
& \text { the individual. }
\end{aligned}
$$

The role of language learning strategy instruction (SI) in promoting learner autonomy is widely recognized and, to this case study, is called upon (Harris, 2003). A debate is upgraded over which ways to approach and implement this framework and guidelines (Wenden, 1991; Little, 1994; Cohen, 1998). The research into language learning strategy instruction stemmed from research of the 'Good Language Learner' (Stern, 1975; Naiman et al.: 1976). Good language learners were found more flexible in orchestrating a stretch of strategies in approaching a language task. Oxford (1990: 8) described this cluster of learners who deploy strategies as 'specific actions taken by the learner to make learning easier, faster, more enjoyable, more self-directed.' Yet, for learners who have a lower command of strategies ought to be assisted towards becoming independent learners during the process of L2 vocabulary 
learning. This could be achieved through instructing learners to apply VLS as efficiently as possible (Ghazal 2007). For there is a rising consensus as well as evidence to suggest that SI is more effective if it is contextualized, so that learners develop their learning strategy repertoire while learning the target language at the same time.' (Cohen, 1998: 80).

\section{Background of the Study}

The term strategies, in the second-language-learning sense, foreshadow the application of intentional conscious moves made by learners with the aim in mind to be useful in learning the second language. Strategies are of different categories, ranging from planning the organization of one's learning process or selecting a certain approach to a task (a Metacognitive learning strategy) by devising mnemonics to learn vocabulary (cognitive learning strategies), and rehearsing what is learned (a performance strategy); this stretch displays the intricacy of learning process in itself. (Cohen 1999: 1)

Research into learning strategies in second language acquisition is not old. According to O'Malley and Chamot (1990: 2-3), 'the notion of learning strategies in second language acquisition emerged in the research literature just over twenty-five years ago. It emerged from a concern for identifying the characteristics of effective learners.' O'Malley and Chamot (1990) categorized learning strategies in second language acquisition into three different groups: Meta-cognitive, cognitive, and socio-affective strategies. Oxford (1990) has also presented a comprehensive classification system of learning strategies. She classified learning strategies into six different categories: memory strategies, cognitive strategies, compensation strategies, Meta-cognitive strategies, affective strategies, and social strategies. These are the most comprehensive categorizations of learning strategies available today. Ellis (1994) argues that these frameworks of categorization pave the way for studying which strategies or the orchestration of several strategies at once are valuable and serve the promotion of autonomy.

According to Ellis (1994: 550), research results conducted in the field of learning strategies is that 'what set the 'effective students' apart was their use of greater range of strategies and, in particular, 'their ability to choose strategies that were appropriate for particular tasks.' This suggests that 'effective learners' are efficient at utilizing Meta-cognitive strategies to choose appropriate cognitive strategies in learning a second language, in the sense that the way strategic learners approach a task and select the appropriate executive strategy is the line that comes between autonomous learners and more dependent, less regulated learners.

\section{Metacognition}

Meta-cognition involves 'active monitoring and consequent regulation and orchestration of cognitive process to achieve cognitive goals.' (Flavell, 1976: 252). May be this definition is found simpler in Anderson (2002: 1) who 
Investigating the Effectiveness of Cognitive Vocabulary Strategy

Instruction in Raising Learners' Metacognitive Awareness for Long-

Term Mass Lexis Learning

defines Meta-cognition as "thinking about thinking." As Anderson states, the use of Meta-cognitive strategies ignites one's thinking and can pinch to higher learning and better performance expected from learners. Furthermore, control over cognitive processes by teachers and guiding as well as directing learners can help second language learners develop their Meta-cognitive processes at once. (Ranjbary \& Rasekh, 2003: 4). This means that if learners are well aware of the approach to take and monitor the route to apply a certain strategy over another, then they are self-evaluating as they progress towards the completion of the task handed. And if teachers tap into the coordination and the overlapping dependence of both cognitive and Meta-cognitive strategies, then it would boost learners stock of strategies and pave the way for them to become autonomous.

Anderson (2002), based on previous research, has proposed five main components for Meta-cognition. They include the preparation and planning for learning, the selection and use of learning strategies, monitoring strategy use, the orchestration of multiple strategies, and finally, the evaluation of strategy use and learning/ completion of the learning task.

Preparation and planning are linked to learners' learning goals. At this stage, learners think about what their goals are -set by the teacher most of the time- and how they ought to accomplish them. The selection and use of particular strategies is a Meta-cognitive ability. Learners, in a given context, make conscious decisions about the learning process; the route about problem solving. What stems from it is that learners' begin to monitor strategy use. By checking periodically whether or not those strategies are effective and being used as intended, and whether or not the goals set are being met. The following stage is to how to use a combination of strategies in an orchestrated fashion. Learners, at this stage, can easily explain the strategies they use and why they employ them. Liang (2010: 155) sates that 'Meta-cognitive strategies are higher order executive skills and include advance organizers, directed attention, selective attention, self-management, advance preparation [...].' And the most important Meta-cognitive strategies is to evaluate effectiveness of strategy use. Self-questioning and self-reflection through the cycle of learning is the final phase. At this level of Meta-cognition, the whole cycle of planning, selecting, using, monitoring and orchestration of strategies is evaluated. (Ranjbary \& Rasekh, 2003).

\section{Vocabulary Learning Strategies}

Years ago, the field of second language acquisition faced the reorientation of interest in several areas of language study, but has taken special notice to vocabulary, and the coming out of a newly recognized aspect - learner strategies (Schmitt, 1997). 
Ellis (1994: 54) summarized the several studies attempted in this field of inquiry and presented a global view to VLS:

The study of vocabulary-learning strategies is a promising area of enquiry. This is because it is possible to define the learning targets and strategies very precisely and also to investigate strategies that have wide currency in the literature.

The fuse and recognition of the importance of both of these areas has led to substantial study in each. Yet, in the place where they cross -vocabulary learning strategies- has attracted a noticeable lack of attention. The way research dealt with vocabulary learning strategies has tended to work on individual or small numbers individual strategies. The state of the area is typified by the lack of a comprehensive list or taxonomy of lexically-focused strategies till the inventory proposed by Schmitt (1997).

The most basic distinction between VLS and learning strategies is that VLS is seen as a sub-category of LLS. Rubin (1987, cited in Schmitt, 1997: 203), defines lexical strategies as 'the process by which information is obtained, stored, retrieved, and used.' But Schmitt (1997) argues that in the case of lexical strategies use should be defined as the practice of vocabulary rather than interactional communication; or more accurately conveying meaning. Even so, the inventory provided by Oxford (1990) is considered as the basis for VLS since several of the language learning strategies in the taxonomy are applied to VLS as well (e.g., memory strategies). Takač (2008: 52) clarifies that the genuine quality of VLS lays in the fact that they are 'specific strategies utilized in the isolated task of learning vocabulary in the target language' and adds that they could be deployed at any field of language learning. He also points to four characteristics whereby VLS:

(1) Require selection on the learners' part, (2)

exhibit complexity and necessitate certain

processes, (3) depend upon learners'

understanding and can further develop

through instruction, and (4) make learning

and using vocabulary in L2 more efficient.(ibid.)

Jurkovic (2006) argues that vocabulary learning strategies make out from learners' development of their own awareness to attempt and figure out the meaning of a new word. Then, how learners ought to retain and store the newly learned word, to retrieving it later on and use it adequately in appropriate contexts.

The taxonomy relied on throughout this research is that of Schmitt (1997). The latter took advantage of Oxford's (1990) classification of language 
Investigating the Effectiveness of Cognitive Vocabulary Strategy

Instruction in Raising Learners' Metacognitive Awareness for Long-

Term Mass Lexis Learning

learning strategies which was compatible and comprehensive to his taxonomy specific to vocabulary learning. The taxonomy of VLS can be divided into two main headings: first; strategies used for the discovery of a new word's meaning and second; strategies used for consolidating a word once it has been encountered. Schmitt (1997) listed 58 strategies falling within these two headings. Furthermore, these 58 strategies were sorted out into, determination, social, memory, cognitive, and Meta-cognitive strategies.

Determination strategies are strategies utilized to reveal the meaning of a word once realized that it was never encountered. Social strategies are strategies deployed by learners to seek out external help like asking a peer or a teacher, etc. Moreover, these can be used to consolidate freshly learned words by interacting, etc. Memory strategies on the other hand, are strategies that involve learners in connecting with the words to be retained with the recent learned/encountered knowledge. As for Cognitive strategies, they are tactical approaches to new words to anchor with prior knowledge like affixations, synonymy, and so on. They also focus on the specific aspects of manipulative mental processes. Last Meta-cognitive strategies are used to plan, control and evaluate learners' own learning by having a conscious overview of the learning process. The following diagram illustrates the categories of VLS.

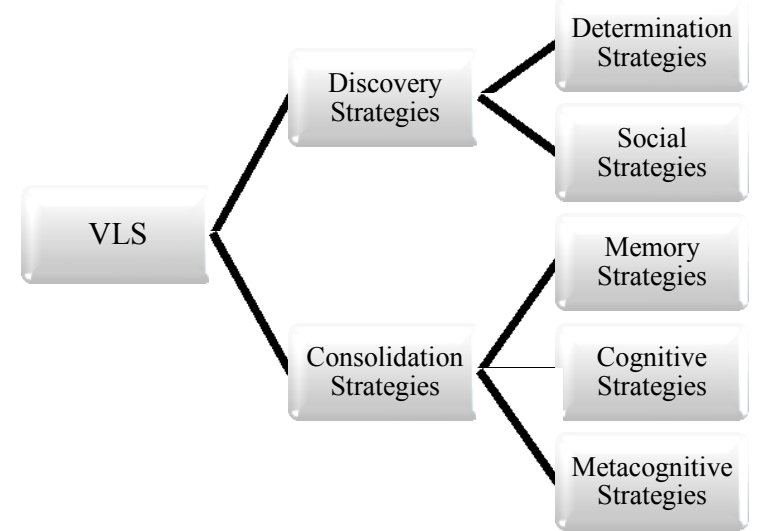

Taxonomy of Vocabulary Learning Strategies (Schmitt, 1997)

\section{The Study}

\section{Participants}

Subjects (96 students) are a representative sample of second year English students from the Mentouri Brothers University of Constantine, Department of Letters and English language. Having learned English as a foreign language for about seven years in school stretching from Middle to High school and two years as a subject study, they have an intermediate level 
of EFL. Subjects will be taught a stretch of strategies and their use throughout the experiment.

Instrumentation

The instruments devised for this study are a questionnaire and a test. The questionnaire was developed with reference to the checklist proposed by Schimdt (1997). It is deployed and conducted to examine learners' backgrounds, knowledge of the strategies and the extent to which they use them or made aware of by teachers.

The whole experiment consisted of three steps: description, instruction, and evaluation. First, subjects completed the questionnaire on vocabulary learning strategies. Second, subjects received instruction and practiced in the use of VLS over multiple sessions throughout several weeks. The first week is intended for the submission of the pre-test. In order to classify learners' strategies and measure their success in them and spot their weaknesses that eventually will guide the procedures of strategy instruction, we devoted the rest for awareness raising and teaching a set of strategies. The units will be developed in accordance with the outcomes of the pre-test. Finally, subjects received a post-test on the VLS to attest for the impact of instruction.

\section{Test Results}

The subjects were randomly divided into two groups: one called the Experimental Group which received the research treatment and the other one is the Control Group which didn't receive any treatment. In other ways, the Experimental Group was taught through direct vocabulary strategy instruction while the teaching of vocabulary learning strategies for the Control Group was incidental; thus, the t-test used in this research is the one for independent groups. Alternatively, in this study, we expect a direction of the Consequence that the treatment will possibly have a positive impact on the experimental Groups' vocabulary learning strategy that is why we consider the test as a onetailed one.

\section{Pre experimental and Pre controlled}

Group Statistics

\begin{tabular}{|c|c|c|c|c|c|}
\hline & group & $\overline{\mathrm{N}}$ & Mean & Std. Deviation & Std. Error Mean \\
\hline \multirow{2}{*}{ nom } &, 00 & 48 & 44,5521 & 4,25171 & ,61368 \\
\hline & 1,00 & 48 & 49,2292 & 3,54299 & ,51139 \\
\hline
\end{tabular}


Investigating the Effectiveness of Cognitive Vocabulary Strategy

Instruction in Raising Learners' Metacognitive Awareness for Long-

Term Mass Lexis Learning

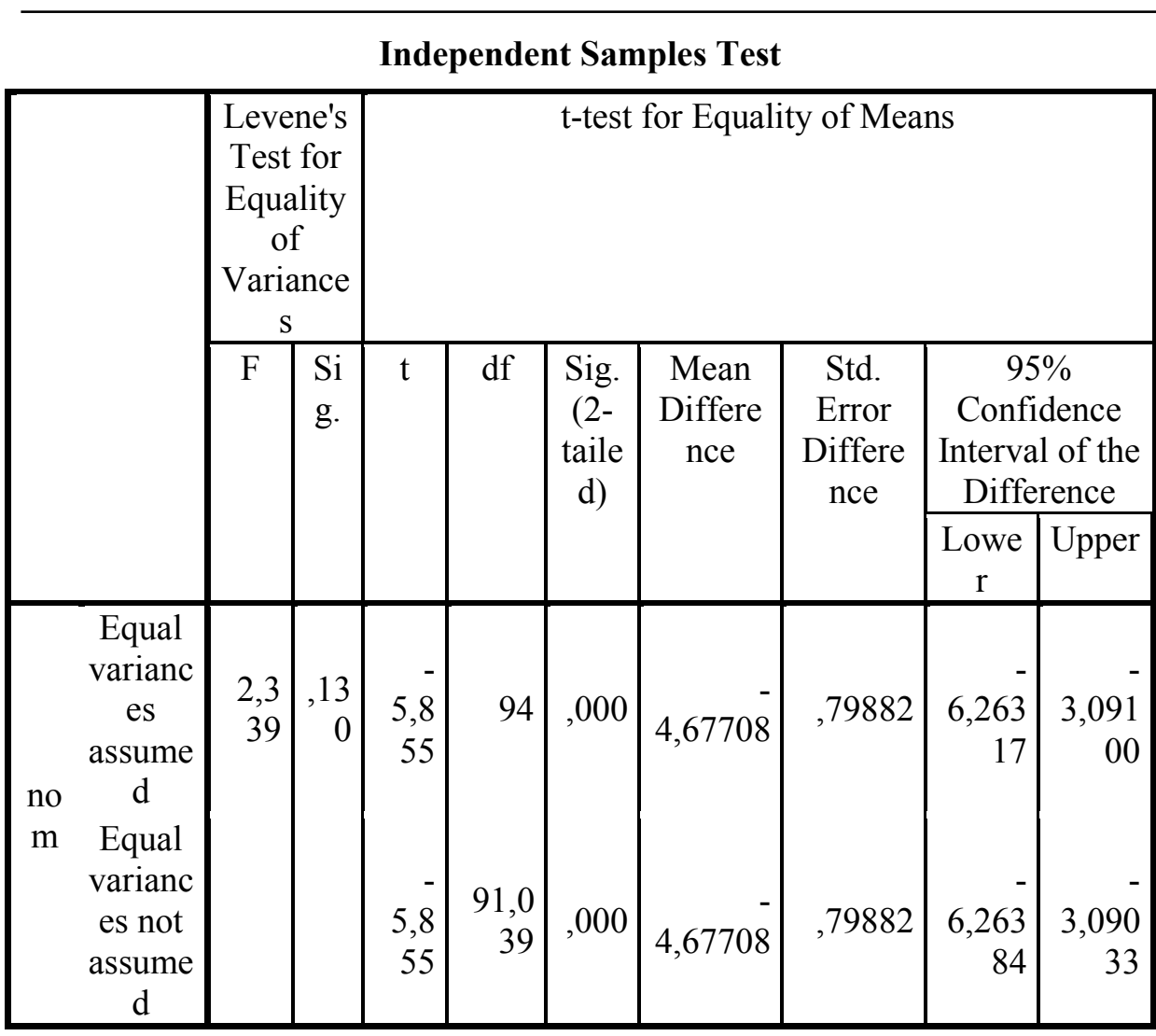

\section{Table 1}

The required $t$ is 1.98 at 0.05 level of significance, and with 94 degree of freedom. The obtained $t$ is 5.85 But we didn't want a two-tailed test; our hypothesis is one tailed and there is no option to specify a one-tailed test in SPSS we will divide the obtained T by 2; thus, it is 2.92 .

Pre experimental and Post experimental

Group Statistics

\begin{tabular}{|c|c|c|c|c|c|}
\hline & group & $\mathrm{N}$ & Mean & Std. Deviation & Std. Error Mean \\
\hline \multirow{2}{*}{ nom } & , 00 & 48 & 55,5313 & 7,09765 & 1,02446 \\
\hline & 1,00 & 48 & 44,5521 & 4,25171 & 61368 \\
\hline
\end{tabular}


Independent Samples Test

\begin{tabular}{|c|c|c|c|c|c|c|c|c|c|}
\hline & \multicolumn{2}{|c|}{$\begin{array}{l}\text { Levene's } \\
\text { Test for } \\
\text { Equality } \\
\text { of } \\
\text { Variance } \\
\text { s } \\
\end{array}$} & \multicolumn{7}{|c|}{ t-test for Equality of Means } \\
\hline & \multirow[t]{2}{*}{$\mathrm{F}$} & \multirow[t]{2}{*}{$\begin{array}{l}\mathrm{Si} \\
\mathrm{g} .\end{array}$} & \multirow[t]{2}{*}{$\mathrm{t}$} & \multirow[t]{2}{*}{ df } & \multirow[t]{2}{*}{$\begin{array}{l}\text { Sig. } \\
(2- \\
\text { taile } \\
\text { d) }\end{array}$} & \multirow[t]{2}{*}{$\begin{array}{c}\text { Mean } \\
\text { Differe } \\
\text { nce }\end{array}$} & \multirow[t]{2}{*}{$\begin{array}{c}\text { Std. } \\
\text { Error } \\
\text { Differe } \\
\text { nce }\end{array}$} & \multicolumn{2}{|c|}{$\begin{array}{c}95 \% \\
\text { Confidence } \\
\text { Interval of the } \\
\text { Difference } \\
\end{array}$} \\
\hline & & & & & & & & $\begin{array}{c}\text { Lowe } \\
\text { r }\end{array}$ & Upper \\
\hline $\begin{array}{ll} & \begin{array}{l}\text { Equal } \\
\text { varian }\end{array} \\
& \text { ces } \\
& \text { assum } \\
\text { no } & \text { ed } \\
\mathrm{m} & \text { Equal } \\
& \text { varian } \\
& \text { ces not } \\
& \text { assum } \\
\text { ed }\end{array}$ & $\begin{array}{r}19,8 \\
58\end{array}$ & $\begin{array}{r}, 00 \\
0\end{array}$ & $\begin{array}{r}9,1 \\
94\end{array}$ & $\begin{array}{r}76,8 \\
83\end{array}$ &, 000 & $\begin{array}{r}10,9791 \\
7 \\
\\
\\
10,9791 \\
7\end{array}$ & 1,19420 & $\begin{array}{r}8,608 \\
05\end{array}$ & $\begin{array}{r}13,350 \\
28\end{array}$ \\
\hline
\end{tabular}

Table 2

The required $t$ is 1.98 at 0.05 level of significance, and with 94 degree of freedom. The obtained $t$ is 9.19 But we didn't want a two-tailed test; our hypothesis is one tailed and there is no option to specify a one-tailed test in SPSS we will divide the obtained T by 2 ; thus, it is 4.59 . AS the obtained $t$ is 4.59 the results are significant, since 4.59 is higher than 1.98; hence, the hypothesis has been proved to be true

Post experimental and post controlled

Group Statistics

\begin{tabular}{|r|l|r|l|r|r|}
\hline & group & $\mathrm{N}$ & Mean & Std. Deviation & Std. Error Mean \\
\hline \multirow{2}{*}{ nom } &, 00 & 48 & 55,5313 & 7,09765 & 1,02446 \\
& 1,00 & 48 & 45,2396 & 2,52433 &, 36436 \\
\hline
\end{tabular}

Independent Samples Test 
Investigating the Effectiveness of Cognitive Vocabulary Strategy

Instruction in Raising Learners' Metacognitive Awareness for Long-

Term Mass Lexis Learning

\begin{tabular}{|c|c|c|c|c|c|c|c|c|c|}
\hline & \multicolumn{2}{|c|}{$\begin{array}{l}\text { Levene's } \\
\text { Test for } \\
\text { Equality } \\
\text { of } \\
\text { Variance } \\
\text { s }\end{array}$} & \multicolumn{7}{|c|}{ t-test for Equality of Means } \\
\hline & \multirow[t]{2}{*}{$\bar{F}$} & \multirow[t]{2}{*}{$\begin{array}{l}\mathrm{Si} \\
\text { g. }\end{array}$} & \multirow[t]{2}{*}{$\mathrm{t}$} & \multirow[t]{2}{*}{$\mathrm{df}$} & \multirow[t]{2}{*}{$\begin{array}{l}\text { Sig. } \\
(2- \\
\text { taile } \\
\text { d) }\end{array}$} & \multirow[t]{2}{*}{$\begin{array}{c}\text { Mean } \\
\text { Differe } \\
\text { nce }\end{array}$} & \multirow[t]{2}{*}{$\begin{array}{c}\text { Std. } \\
\text { Error } \\
\text { Differe } \\
\text { nce }\end{array}$} & \multicolumn{2}{|c|}{$\begin{array}{c}95 \% \\
\text { Confidence } \\
\text { Interval of the } \\
\text { Difference }\end{array}$} \\
\hline & & & & & & & & $\begin{array}{c}\text { Lowe } \\
\mathrm{r}\end{array}$ & Upper \\
\hline $\begin{array}{ll} & \text { Equal } \\
& \text { varian } \\
& \text { ces } \\
& \text { assum } \\
\text { no } & \text { ed } \\
\text { m } & \text { Equal } \\
& \text { varian } \\
& \text { ces not } \\
& \text { assum } \\
& \text { ed }\end{array}$ & $\begin{array}{r}51,7 \\
24\end{array}$ & $\begin{array}{r}, 00 \\
0\end{array}$ & $\begin{array}{r}9,4 \\
65\end{array}$ & $\begin{array}{r}58,7 \\
03\end{array}$ & 000 & $\begin{array}{r}10,2916 \\
7 \\
\\
10,2916 \\
7\end{array}$ & 1,08732 & $\begin{array}{r}8,115 \\
71\end{array}$ & $\begin{array}{r}12,467 \\
62\end{array}$ \\
\hline
\end{tabular}

Table 3

The required $t$ is 1.98 at 0.05 level of significance, and with 94 degree of freedom. The obtained $t$ is 9.46 But we didn't want a two-tailed test; our hypothesis is one tailed and there is no option to specify a one-tailed test in SPSS; we will divide the obtained $\mathrm{T}$ by 2 ; thus, it is 4.73 . As the obtained $\mathrm{t}$ is 4.73 , the results are significant since 4.73 is higher than 1.98 ; hence, the hypothesis has been proved to be true

As it has been shown in table 1, the obtained $t$ is 2.92 and in table 3 , the obtained $t$ is 4.73 . So, we can notice the difference between the results that confirm further our conclusion i.e. the treatment we applied on the experimental group had positive effect by raising learners' Meta-cognitive awareness in learning vocabulary and therefore expand their vocabulary repertoire.

\section{Conclusion}

The current study proposes that systematic strategy instruction results in the improvement of vocabulary strategy use for EFL learners. The present 
research highlights the following expected results: VLS strategy instruction has a positive effect on L2 learners, and that learners gradually become autonomous in learning in general and in learning vocabulary in particular.

\section{REFERENCES}

Aitchison, J.(2003). Words in the Mind. Oxford: Blackwell.

Anderson, N. J. (2002). The role of metacognition in second language teaching and learning. ERIC Digest. Education Resources Information Center.

Brown, A. L. (1987). Metacognition, executive control, self-regulation, and other more mysterious mechanisms. In F. E. Weinert \& R. H. Kluwe (Eds.), Metacognition, motivation, and understanding (pp. 65-116). Hillsdale, New Jersey: Lawrence Erlbaum Associates.

Brown, H. D. (1994). Teaching by Principles: An Interactive Approach to Language Paedagogy. San Francisco: Prentice-Hall, Inc.

Brown, H. D. (2000). Principles of Language and Teaching, Fourth Edition. White Plain, NY: Pearson Education

Brown, H. D. (2001). Teaching by Principles: An Interactive Approach to Language Pedagogy. NY: Longman/ Pearson Education.

Cohen, A. (Ed.). (1998). Strategies in learning and using a second language. London: Longman.

Cohen, A. (Jan. 1999). Strategies in Learning and Using a Second Language. TESL-EJ, (3) 4.

Council of the European Union. (2001). Report from the Education Council to the European Council; the concrete future objectives of education and training systems. Brussels: Council of the European Union.

Ellis, R. (1994). The Study of Second Language Acquisition. Oxford: Oxford UniversityPress.

Flavell, J. H. (1976). Metacognitive aspects of problem solving. In L.B. Resnick (Ed.), The nature of intelligence. Hillsdale, NJ: Erlbaum.

Ghazal, L. (2007). Learning Vocabulary in EFL Contexts Through Vovabulary Learning Strategies. Novitas-Royal, 1(2), 84-91.

Harris, V. (Sep. 2003). Adapting Classroom-Based Strategy Instruction to a Distance Learning Context. TESL-EJ, (7) 2.

Hornby, A. (2000). Oxford Advance Learners' dictionary of Current English. New York: Oxford University Press.

Liang, L. Z. (2010). A Study of English Vocabulary Learning Strategies for Non-English Majors in Independent College. Cross-Cultural Communication, (6) 4, 152-164.

Little, D. (1994). Autonomy in Language Learning; Some Theoretical and Practical Considerations. In Swarbrick, A. (Ed.), Teaching Modern Languages. London. The Open University/ Routledge. 
Investigating the Effectiveness of Cognitive Vocabulary Strategy

Instruction in Raising Learners' Metacognitive Awareness for Long-

Term Mass Lexis Learning

Naiman, N., Frohlich, M., Stern, H. H. \& Todesco, A. (1976). The good language learner. Research in Education Series No. 7. Toronto: The Ontario Institute for Studies in Education.

O'Mally. J. and Chamot, A. U. (1990). Learning Strategies in Second Language Acquisition. Cambridge: Cambridge University Press.

Oxford, R. (1990). Language Learning Strategies: What Every Teacher Should Know. Boston: Hinle \& Hinle.

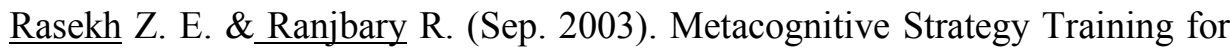
Vocabulary Learning. TESL-EJ, (7) 2.

Richards, C. \& Rodgers, T. (1985). Method: Approach, design and procedure. In Richards, C (Ed.). The Context of Language Teaching. Cambridge: Cambridge University Press.

Schmitt, N. (1997). Vocabulary learning strategies. In N. Schmitt, \& M. McCarthy (Eds.), Vocabulary: Description, Acquisition and Pedagogy (pp.199-227). Cambridge: Cambridge University Press.

Stern, H. (1975). What can we learn from the Good Language Learner? Canadian Modern Language Review, 31, 304-18.

Takač, V. P. (2008). Vocabulary learning strategies and second language acquisition. Clevedon, UK: Multilingual Matters Ltd.

Taylor, L (1990). Teaching and Learning Vocabulary. Prentice Hal New York.

Thornbury, S. (2002). How to Teach Vocabulary. England: Longman.

Wenden, A. (1991). Learner Strategies for Learner Autonomy. Hemel Hempstead: Prentice Hall International (UK). 